\title{
Characterization of in Vitro Shoots Brassica oleracea Results of Cotyledon Explants Induction Using KIN and NAA
}

\author{
Nazirwan Nazirwan, Anung Wahyudi, Ari Wahyuni, Yusanto Yusanto, Desi Maulinda \\ Department of Food Crop Cultivation \\ Politeknik Negeri Lampung \\ Bandar Lampung, Indonesia
}

\begin{abstract}
Vegetative breeding that is mostly done now is through tissue culture techniques. The objective of this research was to obtain a description and examine the influence of the growth regulators 6- Furfuryl amino purine (KIN) and naphthalene acetic acid (NAA) on the formation of in vitro shoots in this cultivar. For this reason, testing is needed to determine the characteristics of the in vitro shoots produced which can be useful as a tool for the formation of synthetic seeds. The ability of cotyledon explants to form the highest shoots (70\%) was in the treatment containing $2 \mathrm{mg} / \mathrm{l} \mathrm{KIN}+0,5 \mathrm{mg} / \mathrm{l}$ NAA but this treatment did not show a significant difference with $2-3 \mathrm{mg} / \mathrm{l} \mathrm{KIN}$ and $2 \mathrm{mg} / \mathrm{l} \mathrm{KIN}+0,5 \mathrm{mg} / \mathrm{l} \mathrm{NAA}$. The percentage of shoot formation correlates closely and positively with the number of culture bottles that form shoots $(r=0.72)$. Based on the description data and the result of the selection of the number of shoots selected two treatment of shoot induction i.e. treatment of $2 \mathrm{mg} / \mathrm{l} \mathrm{KIN}+0.5 \mathrm{mg} / \mathrm{l} \mathrm{NAA}$ which has stem shape of round and straight, and treatment of $1 \mathrm{mg} / \mathrm{l} \mathrm{KIN}+0.5 \mathrm{mg} / \mathrm{l} \mathrm{NAA}$ which also has the same stem shape. Shoots of selected induction results can be used for the formation of synthetic seeds.
\end{abstract}

Keywords-Broccoli, 6-Furfuryl Amino Purine, naphthalene acetic acid, in vitro, description, characteristics, shoot formation, cotyledon, synthetic seeds

\section{INTRODUCTION}

Broccoli is a sub-tropical vegetable, in Indonesia this plant is grown mainly in the temperate regions of the temperate climate, such as Pengalengan, Dieng, Tanah Karo, Lembang, Cipanas and Ciloto. Broccoli (Brassica oleracea L.) plays an important role in the fulfillment of community nutrition. Fresh broccoli contains many substances that are useful for the human body. Vegetable consumption is associated with a reduced risk of diseases such as cancer in humans. This inverse association is greatest when considering cruciferous vegetables [1]. Sulforaphane, a naturally occurring is thiocyanate derived from its glucosinolate precursor glucoraphanin (GFN), is found in cruciferous vegetables such as broccoli. Sulforaphane has been identified as one of the critical bioactive compounds associated with the health benefits following the consumption of these vegetables, and has been shown to play a powerful role in tumour suppression [2]. Other nutrients contained in these vegetables are protein, calcium, vitamin A, ascorbic acid, thiamine, riboflavin and niacin. Efforts to develop broccoli from year to year continue to increase. This gives an indication that the potential for broccoli development is very prospective. There are various obstacles in producing seeds naturally, for example due to the nature of self-compatible plants. In flowering plants, self-incompatibility (SI) is a universal mechanism for avoidance of self-fertilization and inbreeding, thus maintaining their genetic diversity [3]. Naturally, the obstacles to getting seeds can be done through a crossing process but the seeds produced are low and the success rate of hybridization cannot always be guaranteed. Vegetative breeding is a way out to get hybrid seeds of this plant. In this way the superior properties of plants can be maintained. Vegetative breeding that is mostly done now is through tissue culture techniques. This in vitro technique offers a great opportunity to produce desired plants quickly and basically genetically identical. Various tissues have been used in organogenesis of Brassica crops like hypocotyls, cotyledons and leaves [4], shoot tip [5,6]. In vitro regeneration is influenced by many factors such as culture environment, culture medium composition, explant source and genotype [7] For this reason, testing is needed to determine the characteristics of the in vitro shoots produced which can be useful as a tool for the formation of synthetic seeds. This paper reports on the description and influence of KIN alone or KIN combinations with NAA on in vitro shoots formation from broccoli cotyledon explants.

\section{MATERIALS AND METHODS}

The materials tested were cotyledons from hybrid seed sprouts broccoli F-1 Lucky (Primasid) aged 14 days as sources of explants for shoot induction. Before sowing the seeds are sterilized for 15 minutes in $10 \%$ solution and $20 \%$ clorox while shaking. Then the seeds are rinsed with sterile water 3 times to remove the remnants of clorox solution and planted on MS basic media [8]. Basic media used for seed germination and treatment media for shoot induction, before sterilization using autoclaves at $121^{\circ} \mathrm{C}, 1.03 \mathrm{kPa}$ for 30 minutes the $\mathrm{pH}$ of the media was adjusted to 5.7. The levels of KIN concentration used as treatment were 1,2 and $3 \mathrm{mg} / \mathrm{l}$ combined with NAA at 0 and $0.5 \mathrm{mg} / \mathrm{l}$. Cotyledons aged 14 days from normal sprouts of broccoli seeds were cut and inoculated horizontally on the surface of MS treatment media. The explants were cultured in 
$220 \mathrm{ml}$ jam bottles containing $30 \mathrm{ml}$ of media and sealed with aluminum foil. Culture bottles were maintained at $22^{\circ} \mathrm{C}$ and 24 hours of light using cool white fluorescent lamps which gave an intensity of $60 \mu \mathrm{mol} \mathrm{m-2} \mathrm{s}^{-1}$. One pair of cotyledon explants planted for each culture bottle required five culture bottles for each treatment arranged in a Complete Randomized Design (CRD) with 2 replications. Data were analyzed statistically according to the IBM SPSS 24 statistical program and if there were significant different treatments followed by Duncan's multiple distance test at the 5\% level. To see the relationship between percentage data on shoot formation and data on the number of bottles of culture that form shoots, regression correlation analysis was used using SAS program 9.1.

\section{RESULTS AND DISCUSSION}

\section{A. Regeneration of Six Induction Ttreatments using KIN and NAA}

Based on the regeneration data, six induction treatments using KIN and NAA showed that the percentage of cotyledon explants that can form shoots showed significantly different responses (Figure 1).

Experimental result of Nazirwan found that, after 8 weeks of culture, the ability of cotyledon explants to form the highest shoots $(70 \%)$ was in the treatment containing $2 \mathrm{mg} / \mathrm{l} \mathrm{KIN} \mathrm{+0,5}$ $\mathrm{mg} / \mathrm{l}$ NAA but this treatment did not show a significant difference with treatment of $2-3 \mathrm{mg} / \mathrm{l} \mathrm{KIN}$ and $2 \mathrm{mg} / \mathrm{l} \mathrm{KIN} \mathrm{+}$ $0.5 \mathrm{mg} / \mathrm{l} \mathrm{NAA}$ (Figures 1 and 2, F) [9]. The range of KIN concentrations used, with or without NAA, can influence shoot proliferation of broccoli cotyledon explants; increase in KIN concentration singly from $2 \mathrm{mg} / \mathrm{l}$ to $3 \mathrm{mg} / \mathrm{l} \mathrm{KIN}$ or with NAA mainly from $2 \mathrm{mg} / \mathrm{l} \mathrm{KIN}+0.5 \mathrm{mg} / \mathrm{l} \mathrm{NAA}$ to $3 \mathrm{mg} / \mathrm{l} \mathrm{KIN}+0.5$ $\mathrm{mg} / \mathrm{l}$ NAA causes the shoots proliferation rate of cotyledon explants to decrease significantly (Figure 1).

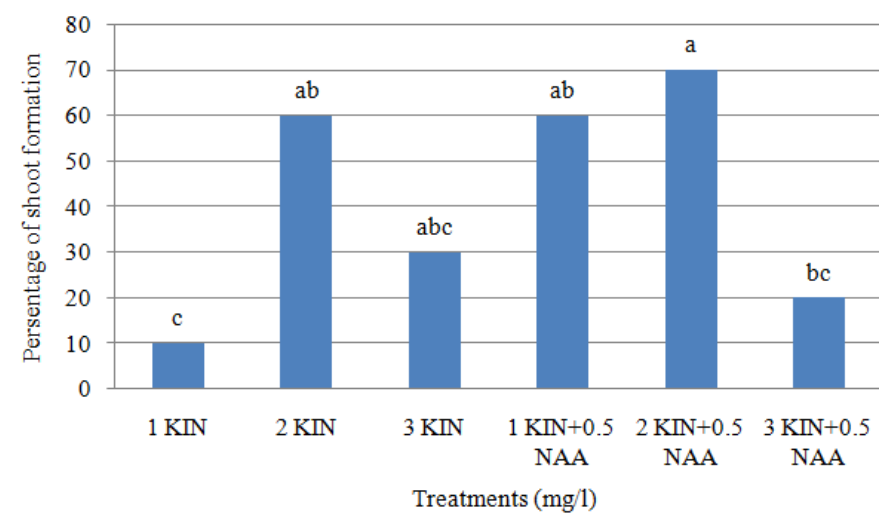

Fig. 1. Effect of various KIN concentrations in combination with NAA on the percentage of broccoli cotyledon explants that produce shoots after eight weeks of culture. The same letter means that it is not significantly different at 0.05 probability level according to Duncan's double distance test.
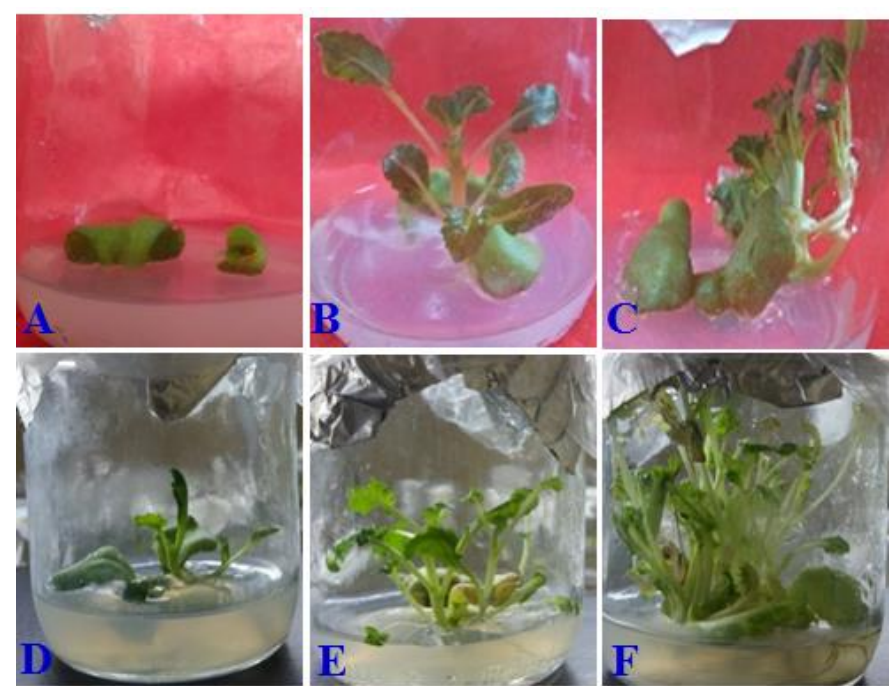

Fig. 2. Multiple shoot formation from cotyledon explants of broccoli on different concentrations of KIN in combination with NAA. A ( $2 \mathrm{mg} / \mathrm{l} \mathrm{KIN} \mathrm{+}$ $0.5 \mathrm{mg} / \mathrm{l} \mathrm{NAA}), \mathrm{B}(1 \mathrm{mg} / \mathrm{KIN}+0.5 \mathrm{mg} / \mathrm{l} \mathrm{NAA})$ and $\mathrm{C}(3 \mathrm{mg} / \mathrm{l} \mathrm{KIN}+0.5$ $\mathrm{mg} / \mathrm{l} \mathrm{NAA})$ after four weeks of culture with D (1 mg/l KIN), E ( $2 \mathrm{mg} / \mathrm{l} \mathrm{KIN})$ and $\mathrm{F}(2 \mathrm{mg} / \mathrm{l} \mathrm{KIN}+0.5 \mathrm{mg} / \mathrm{l} \mathrm{NAA})$ after eight weeks of culture [9].

\section{B. Description of the Six Induction Treatments Using KIN and NAA}

Based on the description data both on induction treatment using KIN singly and on induction treatment using combination between KIN and NAA in this research showed that in the induction treatment using KIN two induction treatment ie treatment $1 \mathrm{mg} / \mathrm{l} \mathrm{KIN}$ and $3 \mathrm{mg} / \mathrm{l} \mathrm{KIN} \mathrm{forming}$ adventitious shoots other treatment ie treatment $2 \mathrm{mg} / \mathrm{l} \mathrm{KIN}$ forming axillary and adventitious shoots. While on treatment using combination between KIN and NAA showed that two induced treatments ie treatment of $1 \mathrm{mg} / \mathrm{l} \mathrm{KIN}+0.5 \mathrm{mg} / \mathrm{l} \mathrm{NAA}$ and $2 \mathrm{mg} / \mathrm{l} \mathrm{KIN}+0.5 \mathrm{mg} / \mathrm{l} \mathrm{NAA}$ formed axillary and adventitious shoots other treatment ie $3 \mathrm{mg} / \mathrm{l} \mathrm{KIN}+0.5 \mathrm{mg} / \mathrm{l}$ NAA formed axillary shoots. Age of shoots formation parameters indicated that all induction treatments had age of shoots formation between 21-56 days after culture (Table I).

TABLE I. DESCRIPTION OF THE SIX INDUCTION TREATMENTS USING KIN AND NAA

\begin{tabular}{|l|l|l|l|}
\hline $\begin{array}{c}\text { KIN } \\
(\mathbf{m g} / \mathbf{l})\end{array}$ & \multicolumn{1}{|c|}{$\begin{array}{c}\text { NAA } \\
(\mathbf{m g} / \mathbf{l})\end{array}$} & \multicolumn{1}{c|}{$\begin{array}{c}\text { Shoot } \\
\text { Type }\end{array}$} & $\begin{array}{c}\text { Age of shoots } \\
\text { formation (DAC) }\end{array}$ \\
\hline 1 & 0 & Adventitious & 56 \\
\hline 2 & 0 & Axillary and adventitious & 35 \\
\hline 3 & 0 & Adventif & 28 \\
\hline 1 & 0.5 & Axillary and adventitious & 21 \\
\hline 2 & 0.5 & Axillary and adventitious & 21 \\
\hline 3 & 0.5 & Axillary & 21 \\
\hline
\end{tabular}

Visual observations on the research were performed on the stem color and stem shape either on induction treatment using KIN singly or on induction treatment using combination between KIN and NAA. Based on the stem color observation data on induction treatment using KIN showed that one treatment of induction treatment of $1 \mathrm{mg} / \mathrm{l} \mathrm{KIN}$ tested had dark green stem color and two other treatments ie $2 \mathrm{mg} / \mathrm{l} \mathrm{KIN} \mathrm{and} 3$ 
$\mathrm{mg} / \mathrm{l} \mathrm{KIN} \mathrm{treatment} \mathrm{having} \mathrm{color} \mathrm{of} \mathrm{stem} \mathrm{light} \mathrm{green.} \mathrm{While} \mathrm{in}$ the treatment using a combination of KIN and NAA showed that all of the induction treatments tested had a light green stem color. On observation of the stem shape both in the induction treatment using $\mathrm{KIN}$ and in the induction treatment using combination between KIN and NAA showed that two induction treatments using KIN tested ie $1 \mathrm{mg} / \mathrm{l} \mathrm{KIN}$ and 3 $\mathrm{mg} / \mathrm{l} \mathrm{KIN}$ treatment had straight rod shape and treatment the other is the treatment of $2 \mathrm{mg} / \mathrm{l} \mathrm{KIN} \mathrm{has} \mathrm{a} \mathrm{round} \mathrm{shape} \mathrm{of} \mathrm{the}$ stem is straight and round shape of the stem is not straight. Meanwhile, in the treatment using a combination of KIN and NAA showed that all induction treatments tested had a straight round shape (Table 2).

TABLE II. VISUAL OBSERVATION OF STEM COLOR AND STEM SHAPE OF Plants ON SiX INDUCTION TREATMENTS USING KIN AND NAA

\begin{tabular}{|l|l|l|l|}
\hline KIN (mg/l) & NAA (mg/l) & \multicolumn{1}{|c|}{ Stem color } & \multicolumn{1}{c|}{ Stem shape } \\
\hline 1 & 0 & Dark green & Round and straight \\
\hline 2 & 0 & Light green & Round and not straight \\
\hline 3 & 0 & Light green & Round and straight \\
\hline 1 & 0.5 & Light green & Round and straight \\
\hline 2 & 0.5 & Light green & Round and straight \\
\hline 3 & 0.5 & Light green & Round and straight \\
\hline
\end{tabular}

\section{Number of Shoots}

Based on statistical analysis showed a significant difference between induction treatment using KIN singly and in combination treatment between KIN and NAA (Table 3). While based on data on the number of culture bottles forming shoots showed that the induction treatment of $2 \mathrm{mg} / \mathrm{l} \mathrm{KIN}+0.5$ $\mathrm{mg} / \mathrm{l}$ NAA resulted seven culture bottles that forming shoots significantly different than the other induction treatment (Figure 3). In the induction treatment $2 \mathrm{mg} / \mathrm{l} \mathrm{KIN} \mathrm{was} \mathrm{not}$ significantly different from the treatment of $1 \mathrm{mg} / \mathrm{l} \mathrm{KIN}+0.5$ mg/l NAA.

TABLE III. OBSERVATION OF THE NUMBER OF CULTURE BOTTLES TO FORMED SHOOTS AT SIX INDUCTION TREATMENTS USING KIN AND NAA

\begin{tabular}{|l|l|l|}
\hline $\begin{array}{c}\text { KIN } \\
(\mathbf{m g} / \mathbf{l})\end{array}$ & \multicolumn{1}{c|}{$\begin{array}{c}\text { NAA } \\
(\mathbf{m g} / \mathbf{l})\end{array}$} & Number of shoots (bottles) \\
\hline 1 & 0 & $1 \mathrm{a}$ \\
\hline 2 & 0 & $6 \mathrm{~d}$ \\
\hline 3 & 0 & $3 \mathrm{c}$ \\
\hline 1 & 0.5 & $6 \mathrm{~d}$ \\
\hline 2 & 0.5 & $7 \mathrm{e}$ \\
\hline 3 & 0.5 & $2 \mathrm{~b}$ \\
\hline
\end{tabular}

The same letter means that it is not significantly different at 0.05 probability level according to Duncan's double distance test.
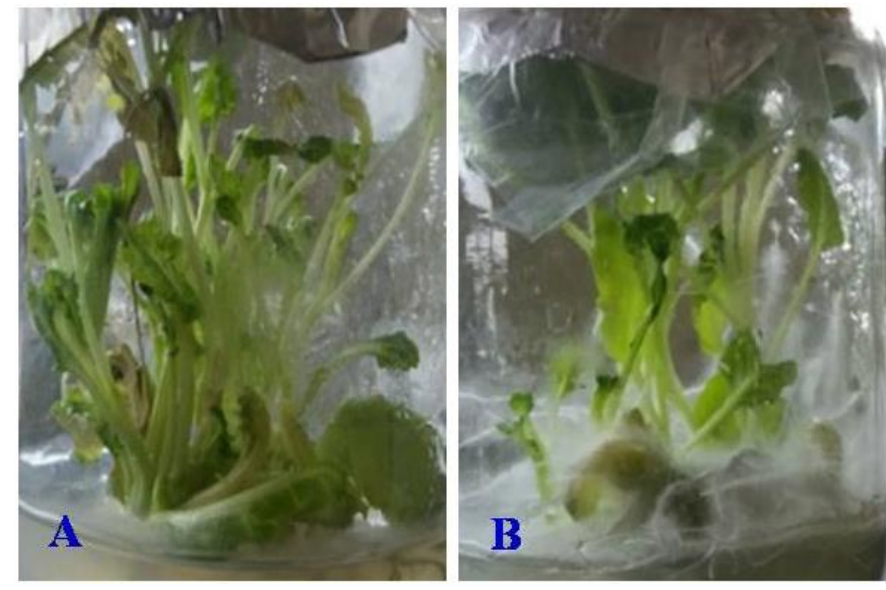

Fig. 3. Multiple shoot formation from cotyledon explant of broccoli on different concentrations of KIN in combination with NAA. A ( $2 \mathrm{mg} / \mathrm{l} \mathrm{KIN} \mathrm{+}$ $0.5 \mathrm{mg} / \mathrm{l} \mathrm{NAA})$ and $\mathrm{B}(1 \mathrm{mg} / \mathrm{l} \mathrm{KIN}+0.5 \mathrm{mg} / 1 \mathrm{NAA})$ after eight weeks of culture.

The difference in the number of culture bottles that form shoots between induced treatments is due to the interaction between KIN concentrations and the combined treatment of KIN and NAA concentrations. Thus the characters contained in the shoots continuously will respond and adjust to the concentrations of growth regulators and the proportion of concentrations between growth regulators.

\section{The relationship between the percentage of shoot formation and the number of culture bottles that form shoots}

Based on data on the percentage of shoot formation (Figure 1) and data on the number of bottles of culture that form buds (Table 3), it can be seen the correlation between the data of percentage of shoot formation with variable data on the number of culture bottles that form shoots as presented in Figure 4.

Based on the results of regression analysis, the relationship between the variable data on the percentage of shoot formation with variable data on the number of culture bottles that form shoots based on statistical tests showed that the percentage of shoot formation correlates closely and positively with the number of culture bottles that form shoots $(r=0.72)$. This means that the higher the percentage of shoot formation, the greater the number of culture bottles that form shoots or vice versa. In Figure 4 above, it appears that the value of $\mathrm{R}^{2}=$ 0.514 ; It can be interpreted that the data from the percentage of broccoli shoots formation correlates closely and positively with data from the variable number of culture bottles that can form shoots that is $51.4 \%$ while the rest can be caused by the influence of other variables not included in this study. 


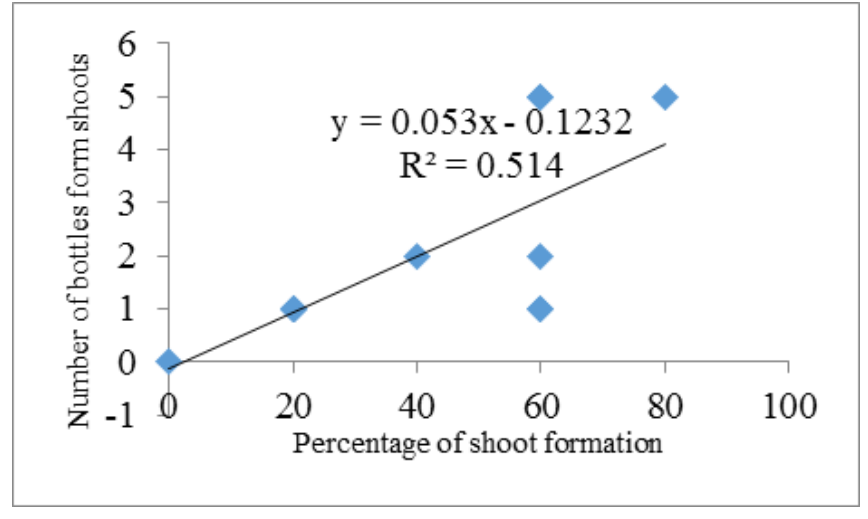

Fig. 4. The relationship between the percentage of shoot formation and the number of culture bottles forming shoots. Value of $\mathrm{R}^{2}=0.514$ obtained based on the results of regression correlation analysis using SAS program 9.1.

\section{E. Selected Induction Treatment}

Based on the description data and the result of the selection of the number of shoots selected two treatment of shoot induction ie treatment of $2 \mathrm{mg} / \mathrm{l} \mathrm{KIN}+0.5 \mathrm{mg} / \mathrm{l} \mathrm{NAA}$ which has stem shape of round and straight and treatment of $1 \mathrm{mg} / \mathrm{l}$ $\mathrm{KIN}+0.5 \mathrm{mg} / \mathrm{l} \mathrm{NAA}$ which also has the same stem shape. Shoots of selected induction results can be used for the formation of synthetic seeds.

\section{CONCLUSION}

Research result showed that, the ability of cotyledon explants to form the highest shoots $(70 \%)$ was in the treatment containing $2 \mathrm{mg} / \mathrm{l} \mathrm{KIN}+0,5 \mathrm{mg} / \mathrm{l} \mathrm{NAA}$ but this treatment did not show a significant difference with $2-3 \mathrm{mg} / \mathrm{l} \mathrm{KIN}$ and $2 \mathrm{mg} / \mathrm{l}$ $\mathrm{KIN}+0,5 \mathrm{mg} / \mathrm{l} \mathrm{NAA}$. The percentage of shoot formation correlates closely and positively with the number of culture bottles that form shoots $(r=0.72)$. Based on the description data and the result of the selection of the number of shoots selected two treatment of shoot induction i.e. treatment of 2 $\mathrm{mg} / \mathrm{l} \mathrm{KIN}+0.5 \mathrm{mg} / \mathrm{l} \mathrm{NAA}$ which has stem shape of round and straight, and treatment of $1 \mathrm{mg} / \mathrm{l} \mathrm{KIN}+0.5 \mathrm{mg} / \mathrm{l} \mathrm{NAA}$ which also has the same stem shape. Shoots of selected induction results can be used for the formation of synthetic seeds.

\section{ACKNOWLEDGMENT}

The authors are thankful to the Department of Food Crop Cultivation Politeknik Negeri Lampung, for the laboratory facilities provided.

\section{REFERENCES}

[1] K.J. Royston and T.O. Tollefsbol, "The epigenetic impact of cruciferous vegetables on cancer prevention," Current Environmental Health Reports, vol. 1, pp. 46-51, 2015.

[2] A. Hsu, C.P. Wong, Z. Yu, D.E. Williams, R.H. Dashwood and E. Ho, "Promoter de-methylation of cyclin D2 by sulforaphane in prostate cancer cells," Clinical Epigenetics, vol. 3, pp. 3, 2011.

[3] S. Takayama and A. Isogai, "Self-incompatibility in plants," Annu Rev Plant Biol., vol. 56, pp. 467-489, 2005.

[4] B. Javed, S.H. Farhatullah, Shah and I. Ali, "In vitro analysis of callus induction in interspecifically hybridized f4-5 populations of Brassica," Pak. J. Bot., vol. 44, no. 2, pp. 787-790, 2012.

[5] H. Abbas, M. Qaiser and S.W. Khan, "In vitro response of Convolvulus scindicus to different growth hormones-an attempt to conserve an endangered species," Pak. J. Agri. Sci, vol. 49, no. 1, pp. 41-45, 2012.

[6] M. Asim, "Micropropagation of lentil (Lens culinaris Medik.) using pulse treatment of immature plumular apices," Pak. J. Agri. Sci., vol. 49, pp. 149-154, 2012.

[7] R. Bano, M.H. Khan, R.S. Khan, H. Rashid and Z.A. Swati, Development of an efficient regeneration protocol for three genotypes of Brassica juncea. Pak. J. Bot, vol. 42, no. 2, pp. 963-969, 2010.

[8] T. Murashige and F. Skoog, "A revised medium for rapid growth and bioassay with tobacco tissue culture," Physiol. Plant., 15, 473-497, 1962.

[9] Nazirwan, "In vitro shoot generation from cotyledon explant of brassica oleracea using KIN and NAA," G.J.B.A.H.S., vol.6, no. 4, pp. 12-14, 2017. 